\title{
THE CONCEPT OF BUILDING A SUPPLY CHAIN IN THE FAST FASHION CLOTHING INDUSTRY
}

\author{
Sławomir Jarka \\ Warsaw University of Live Sciences, Faculty of Ecnomics, Nowoursynowska 166 Street, 02-787 Warsaw, Poland, EU, \\ slawomir_jarka@sggw.pl
}

Keywords: supply chain, nearsourcing, fast fashion

Abstract: Nowadays, supply chains must be adapted to constant changes taking place in the company's environment, therefore, the need to efficiently configure and reconfigure them is fundamental. The study presents the specificity of the clothing industry, which defines the role of fast fashion business strategy in building a competitive advantage. On the basis of literature studies, the directions of development of the supply chain in the analysed industry were indicated.

\section{Introduction}

The feature of modern business is the very strong competition between enterprises that carry out all processes in the international economic space, locating individual links of their logistics systems in precisely defined regions of the world. Nowadays, supply chains must be adapted to constant changes taking place in the company's environment, therefore, the need to efficiently configure and reconfigure them is fundamental. These activities are constantly enforced by growing customer expectations, rapid changes in demand and supply, competition or a variety of technological innovations. These technological innovations force corporations to invest globally in their supply, production and distribution networks. The aim of the research was to determine the direction of changes in the clothing industry, with particular emphasis on supply chains and production placement. The clothing industry is one of the most dynamically changing industries in the world. Fashion, all trends, over a dozen collections during the year make it a very difficult market for enterprises, and the moment of inattention can lead to the edge of bankruptcy. The study presents the specificity of the clothing industry, which defines the role of fast fashion business strategy in building a competitive advantage. On the basis of literature studies, the directions of development of the supply chain in the analysed industry were indicated.

\section{Characteristics of the Fast Fashion industry}

Contemporary clients actively search for products using the Internet and thanks to the efficient flow of information, they gain access to market novelties much faster. As a result, they began to demand continuous updating and improving the offer. The impatient clients created a completely new market and clothing industry, shortening the life cycle of products and imposing a very high rate of introducing new products. This required the clothing industry to improve the organizational efficiency of enterprises that tried to keep up with consumer expectations. The essence of this business model is to maximally shorten the preparation time of the collection and the life cycle of the finished product. The products are placed on the market in small quantity batches, with very high frequency. As a result, goods change so often in stores, that it encourages customers to frequent visits and the client compares different brands, visits those that are characterized by a large variability of the offer. This approach has strategic features and requires an organizational commitment of the entire enterprise.

Fast Fashion is a term that primarily defines the business and sales strategy of textile and clothing enterprises. This concept puts a special emphasis on satisfying customers' needs in terms of two key elements speed and diversity, at the lowest possible price [1].

In practice, this means quick trend updates, a shorter life cycle of products and low prices as well as high flexibility against changing demand. The most important priorities of the Fast Fashion strategy concept are:

- $\quad$ Speed - this concept is based on reducing the time of the flow of goods, information throughout the supply chain - from the preparation of product concepts, through their production, to delivery to stores, all in order to increase customer satisfaction. Compared to traditional models based on long-term forecasts, the time is shortened from 52 to 2-4 weeks. In the face of ever-changing trends, and thus the ever-changing demand for these goods, enterprises faced an extremely difficult challenge to meet these requirements.

- The golden mean according to this concept is the total concentration on time - the most important factor shaping the value of the product, and as a result, the customers' purchasing tendencies. Hence, time dethrones the price and becomes the main priority of the modern clothing industry. Consequently, by moving production to regions closer to places of consumption of goods and shortening delivery time; demand and life cycle of products - the previously mentioned speed of delivering novelties to the market is the key to the success of enterprises in the contemporary fashion industry. Accordingly, this feature 
adds value to the goods and makes them capable of satisfying the needs of customers.

\section{Result and discussion}

K. Rutkowski defined the configuration of the supply chain as a combination - arrangement of its key elements, whereas reconfiguration as the ability to introduce changes in this combination / arrangement [2]. The purpose of the reconfiguration is to improve the functioning of the supply chain and the essence of it are significant changes in its subjective and process layout, which aim to improve efficiency in terms of flexibility, speed, reliability, quality and costs. All activities related to configuration and reconfiguration of the supply chain are crucial in the strategic management of the supply chain, thus determining further aspects of the operational functioning of the logistics network. According to Hout [3], companies competing on global markets apply strategies:

- $\quad$ Multilocal - geographic distribution of activities and its loose coordination; local supply and local production; customized products targeted at local customers. The goal was a regional competitive advantage; used by companies with branches in different regions of the world;

- Transnational, including global strategies competitive advantage seen mainly in the economies of scale and integration of business activities in various markets. The goal was to focus on standardization in all markets.

Along with the intensification of globalization processes, most corporations began to abandon multilocal strategies for global strategies, which resulted in, among others, limiting the competences of local branches and departments. In addition, the development of information and communication technologies entails the integration of marketing, procurement, production and distribution processes, resulting in a virtually complete departure from multilocal strategies. Global strategies assume competition wherever it is possible. The existing transnational management models predict a strong unification of consumer needs from different parts of the world, which results in the offer of standard, almost identical products. However, recently it has been noticed that such an approach is not very effective, which will probably force large-scale application of compromise solutions that reconcile various expectations of recipients and maximize global efficiency - economies of scale or cost reduction. The Inditex company owes its increased effectiveness especially on the European market to such a configuration - global, multidimensional configuration of processes such as design, production, procurement, marketing or distribution. The use of international space and adding value guarantees building an advantage over competitors and achieving assumed strategic benefits. International clothing companies operating in a dynamically changing environment will eventually be forced to change the location and number of suppliers, production plants and distribution centres, similar to the mentioned Inditex. In such models, it will be possible to observe a strong restructuring of the complex logistic network, which will have to face the ability to easily change and adapt.

Table 1 Division of the motifs of delocalisation of the value chain modules by group of factors [4]

\begin{tabular}{|c|c|}
\hline Cost Motives & Resource Motives \\
\hline 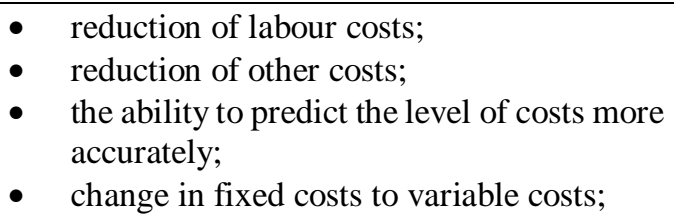 & $\begin{array}{l}\text { - } \quad \text { access to qualified personnel; } \\
\text { - } \quad \text { focus on key competences; } \\
\text { - } \quad \text { access to new technologies; }\end{array}$ \\
\hline Organizational Motives & Market Motives \\
\hline $\begin{array}{l}\text { - improvement of the level of services } \\
\text { provided and the quality of products; } \\
\text { - } \quad \text { implementation of development strategies; } \\
\text { - improving the efficiency of the entire } \\
\text { system; } \\
\text { - changes in business processes; }\end{array}$ & $\begin{array}{l}\text { - } \quad \text { faster access to markets; } \\
\text { - } \quad \text { access to new markets; } \\
\text { - } \quad \text { comping the company's response time; } \\
\text { - } \quad \text { adaptation to the behavior of other entities; }\end{array}$ \\
\hline
\end{tabular}

Difficult strategic decisions regarding the location of production facing the clothing industry are the key to effective functioning, development and survival. Transnational and global strategies, especially the clothing industry, in the original version emphasized mainly the cost motives - extreme reduction of labour costs, which resulted in the transfer of production to countries such as China or Bangladesh. However, the experience of the last twenty years has shown that the other factors - resource, organizational or market - are equally important and their optimal combination ensures competitiveness. This is the reason why many companies such as American Apparel [5] and GAP, which have been intensively applying economies of scale and extreme cost reduction, etc., have found themselves on the verge of bankruptcy. Attempts to optimize costs only in individual parts of the chain caused 
that costs grew rapidly in subsequent stages. The lack of a holistic approach made it impossible to predict the total amount of costs, not to mention the multiplicity of crises throughout the entire chain. The division into four groups of factors allows a more holistic approach to the problem because it presents different elements of the chain (Table 1). Research by K. W. Platts and N. Song showed that enterprises have to reckon with approximately $50 \%$ higher outsourcing costs than originally expected [6]. This perfectly highlights the problems of proper configuration of the supply chain of the Fast Fashion clothing industry. In the past, the main determinant was to reduce production costs by moving it to countries such as China and Bangladesh. Rising crude oil prices (on the Shanghai - New York route in 2000 , the cost of one container was about $\$$ 3,000 , while in 2008 it was almost $\$ 8,000$ ), therefore, rising transport costs have made it not the only valid indicator of choosing the right, economically sustainable business strategy [7].

Many enterprises are not aware of the difficulties of the adopted strategy and do not overestimate costs, which often wrongly identifies outsourcing to countries such as China with being economical. This is primarily due to the concern for acquiring cheap labor in developing countries, with the lack of knowledge related to the risk incurred [7]. In addition, K.W. Platts and N. Song indicate that outsourcing carries a number of risks related to factors such as:

- Currency fluctuations (difficulties in estimating real costs),

- Increase in oil prices (increase in transport costs and plastic packaging),

- Political instability,

- Excessive bureaucracy ("long product waiting time for documents"),

- Unforeseen costs (the longer the chain, the more critical points and unexpected difficulties),

- A large number of defective products (necessity of returning goods, prolonged waiting time for products, complaints, deterioration of the image, etc.),

- Communication difficulties between businesses collaborates (ignorance of foreign languages, inadequate telecommunications technologies).

Backelin and Welchermill particularly emphasize the problems of cultural differences and the problems that arise from them. During his professional career, he noticed that the Chinese, but also the population of other nationalities in this region is characterized by a certain peculiarity "reluctance to disgrace, to lose the good name." What, as the above-mentioned Authors say, means more or less, "the Chinese never say no", even when they do not understand the orders or are not able to fulfil the order [7]. According to Backelin and Welchermill, it is precisely due to communication and cultural difficulties that a large part of the quality problems arise, as well as the necessary excessive amount of control, which is also very expensive.
Lilja from H\&M additionally emphasizes the difficulties associated with transport to such a distance - above all, time and unforeseen costs associated with various types of accidents or disasters. Estimating that about $10 \%$ of transport must be renewed by airway.

\section{Conclusions}

The Forum for the Future organization forecasts that by 2025 , the human population will increase by 1 billion. However, the number of elderly people will be more than twice as large as today. At the same time, the demand for water, energy and food will increase, which will result in higher prices, and access to these resources will become a key political issue. These are not the only problems the industry is facing, the next significant are climate changes that will have a strong impact on agriculture. Repetitive droughts, floods, tsunamis and other catastrophes of this type will additionally intensify the increase of prices of primary commodities. At the same time, it is expected that this will intensify demographic problems and may lead to the escalation of further conflicts and migrations of millions of people. Natural disasters will raise prices of cotton, silk, wool or hides. The intensifying conflicts will continue to drive the increase in rates for crude oil, from which various synthetic fibres are produced. Other factors will also shape the modern world, for example, Far Eastern countries such as China and India will exert an increasingly significant influence on the international economy. The increasing number of people and the simultaneous enrichment of society from these regions will completely change the balance of power in the world. Technology and the Internet will continue to change the lives of billions of people. That is why building flexible and economically, socially and ecologically sustainable supply chains is so important. In industries with a high degree of competitiveness, such as Fast Fashion, the ability to react quickly determines the situation and market position of enterprises. The trend to reduce operating costs, including logistic costs, means that companies often lose it, which is why it is necessary to use a mix of many concepts, including:

- nearsourcing;

- using the services of specialized logistic operators, especially those serving the e-commerce market;

- fast rotation in the chain;

- efficient consumer response (ECR),

- information technologies that support efficient management:

- automatic data identification systems,

- database technologies,

- Integrated IT systems.

Logistic operators that are real intermediaries of physical flow between suppliers and customers have not even been treated as the next link in the supply chain, only the operational background. It caused a number of negative consequences, such as cell positioning and lack of 
understanding of their problems, which led to a decrease in the quality of services offered. With ECR, operators can bring a certain value to the Fast Fashion supply chain and even increase it.

\section{References}

[1] ROHWEDDER, C.: Making fashion faster, The Wall Street Journal, Online, Available: http://www.kellogg. northwestern.edu/course/opns430/modules/supply_ch ain_management/WSJFastFashion.pdf [16 Sep 2018].

[2] RUTKOWSKI, K.: Restrukturyzacja globalnych łańcuchów dostaw a atrakcyjność inwestycyjna Polski, Gospodarka Materiatowa $i$ Logistyka, Vol. 2013, No. 12, p. 2-9, 2013. (Original in Polish)

[3] HOUT, T., PORTER, M.E., RUDDEN, E.: How global companies win out, Harvard Business Review, Vol. 1982, No. 5, p. 9-10, 1982.

[4] DZIKOWSKA, M.: Działalność przedsiębiorstw w erze delokalizacji modułów łańcucha wartości,
Economic Studies, Vol. 2012, No. 3, Wydawnictwo Polskiej Akademii Nauk, Instytutu Ekonomicznego, p. 411-429, 2012. (Original in Polish)

[5] FARRELL, S.: American Apparel files for bankruptcy, The Guardian, Online, Available: http://www.theguar dian.com/business/2015/oct/05/american-apparelfiles-for-bankruptcy [17 Sep 2018], 2015.

[6] PLATTS, K.W., SONG, N.: Overseas sourcing decisions - the total cost of sourcing from China, Supply Chain Management: An International Journal, Vol.15, No.4, p. 320-331, 2010.

[7] BACKELIN, D., WELCHERMILL, P.: Sustainable outsourcing, Trends in the clothing industry, Online, Available: http://kth.divaportal.org/smash/get/diva2:649414/FULLTEXT01.pdf [16 Sep 2018], 2013.

\section{Review process}

Single-blind peer review process. 